Article

\title{
The Culture of Professional Self-Realization as a Fundamental Factor of Students' Internet Communication in the Modern Educational Environment of Higher Education
}

\author{
Maria Odinokaya, Tatyana Krepkaia, Oksana Sheredekina and Maya Bernavskaya *(D) \\ Graduate School of Foreign Languages, Institute of Humanities, Peter the Great St. Petersburg Polytechnic \\ University, Polytechnicheskaya, 29, 195251 St. Petersburg, Russia \\ * Correspondence: bernavskaya@mail.ru; Tel.: +7-921-983-7458
}

Received: 11 May 2019; Accepted: 12 July 2019; Published: 17 July 2019

\begin{abstract}
This article deals with the problem of the culture of professional self-realization of Russian students in the process of university education at the present stage. The role of information and communications technologies is revealed, in particular the interactive technology of self-regulation developed by the authors, as a necessary pedagogical condition for the successful professional self-realization of students. The paper describes the interactive technology of self-regulation formation used in teaching a foreign language in order to improve the educational process. The paper provides an analysis of the current state of the classroom educational environment in teaching a foreign language in order to determine the possibilities of improving the educational process. The main goal of the interactive technology of self-regulation formation is to optimize and intensify the activities of students in the classroom and extracurricular activities. The interactive technology of self-regulation formation in a nonlinguistic university was applied in the proposed work. Special attention was paid to the problem of structuring and the algorithmization of independent work. Ways for increasing interactivity are revealed, and an algorithm for teaching and speech actions in interactive mode was developed. It was established that the introduction of structured algorithmization using the interactive technology of self-regulation formation could be effectively used for teaching poorly prepared students. It has been established that the culture of professional self-actualization for modern students is directly dependent on the quality of online interaction with a university teacher. It was revealed that it is the student's awareness of the objectives of learning interaction and ways for its implementation that allow him to competently perform his academic work, which in turn contributes to the actualization of personal professional qualities that are required by a university graduate for successful implementation in the future.
\end{abstract}

Keywords: culture of professional self-realization; student; informatization; information and communication technologies; interactive technology; independent work of the student; higher school

\section{Introduction}

One of the main tasks of the education system at the present stage is to improve the quality of training of highly qualified and competitive personnel for all sectors of production, culture, science, and education. In recent decades, researchers have recognized that the status of culture in people's minds and in their theoretical concepts seems extremely high [1-4]. This position has been confirmed in the scientific literature on both a domestic and global scale $[5,6]$. Such a variety of studies indicates a high interest in the problem and its relevance to the current educational situation in the system of higher education and the theory and methodology of vocational education. 
Professional self-realization of students in modern society is a multifaceted problem of higher education that is associated with the actual social problems that determine both the current socioeconomic climate and the future situation [7-9]. Various countries are rapidly adapting to the global information space, developing and mastering the latest information and communication technologies, forming a specific legislative framework, forming and implementing distance forms of education, etc. One of the major sociocultural factors shaping the culture of professional self-realization of students is internet communication, which is getting a leading role in the field of student culture $[10,11]$.

\section{Materials and Methods}

The materials of the research were restricted to papers extracted from the Scopus database. The materials of the research were publications containing scientifically based data on the pedagogical essence of self-realization, the culture of professional self-realization of a student, and the possibilities and peculiarities of courses for students of a certain age. The types of publications included articles, conference papers, and literature reviews, as such publications tend to most fit the idea of cutting-edge research.

The main research methods were search strategies, theoretical analysis of sources, and synthesis of the information presented within them.

The process of informatization of a society is accompanied by the approval of a new system of values and new principles of business culture, including the culture of professional self-realization [12-15]. Self-realization is understood by us as the free activity of a student, determined by the nature of the goal and the measure of its personal understanding and acceptance. The need for self-realization is a leading need, the source of personal and semantic activity of a student aimed at continuous self-improvement. Studies have demonstrated the presence of a variety of theoretical and methodological approaches to the formation of a professional culture of specialists [16-18].

Professional culture is given a different interpretation, in a generalized form understanding it as an ability, as a complex of knowledge, skills, and abilities that make a specialist of each particular type of work a master of his craft. In our study, under the professional self-realization of students, we understand the complexity of the most active educational practices of student culture, formed and modernized by students independently and aimed at the implementation of their general cultural and narrow professional experience.

There have been a number of works that have revealed certain aspects of professional culture. Professional culture might shape the interorganizational exchange of personal information in a health and social care context. A simplified model of possible information-sharing behaviors ("ideal", "over-open", "over-cautious", and "chaotic") can be explored to suggest that patterns of information-sharing may be influenced by a number of factors that include not only interprofessional differences in the approach taken to information-sharing but also the ways in which the professions interrelate [19].

A focus on professional culture, including the partial "re-education" and "reprogramming" of students of higher educational institutions whose knowledge was based on the training that students received in previous stages of training, has been considered [20]. Interesting results were obtained: Available information technologies, context, professional culture, and interaction are the key factors influencing the transfer of knowledge. Cultural filters appear to influence people's perception of their professional roles, their vision of the applicability of technology to social issues, and their view of the possibility of knowledge transfer [21]. Managing aspects of professional culture can help maintain the internal motivation of professionals without causing side effects of monetary incentives. Managing dimensions of professional culture can help support professionals' intrinsic motivation without incurring the side effects of monetary incentives [22].

The engineering profession has a culture that encompasses values, beliefs, attitudes, customs, and behavior [23]. The professional culture of engineers developed as different professions evolved, reflecting historical factors as well as social problems. The educational experiences and socialization 
processes that take place during the training of each engineer reinforce common values, problem-solving approaches, and the language of each profession. An increase in specialization has led to an even greater immersion of students in the knowledge and culture of their own professional group [24].

We can also assume that student culture has two vectors of integration: Local (national) and global (international). We can say that currently the most common value of student culture is information mobility [25-29], which includes both an accumulated amount of knowledge and skills and a symbiosis of technical means and skills of ownership, allowing for communication in the shortest possible time in order to obtain the applied information necessary at that moment.

The object of our attention, the modern media culture of students, is at the junction of a whole complex of humanitarian branches of knowledge: Cultural studies, psychology and pedagogy, sociology, metalinguistics and semiology, theory and history of journalism, etc. [30,31]. The problems of the culture of professional self-realization as a part of the internet communication of students are in the sphere of problems of modern media culture and media education, to which researchers pay special attention [32].

Internet communication is the newest sphere of professional self-realization of students, where there has been a transformation of all traditional educational practices and implemented innovative potential of student culture in terms of the formation and development of new educational practices and cultural values $[33,34]$. The culture of professional self-realization as a part of the internet communication of students can be an open global (international) platform for the development of student culture and, based on the social significance of student culture, a platform for further design and development of global cultural processes. The leading aspect of the modernization of education is to prepare the younger generation for life in a rapidly changing information society in a world where there is a constant need for new professions and continuous professional development [35-41]. Currently, one of the main goals of innovation is the development of students' teaching abilities in independently navigating the world of information.

Internet communication is the newest sphere of professional self-realization of students, in which there is a transformation of all traditional educational practices and implemented innovative potential of student culture in terms of the formation and development of new educational practices and cultural values $[33,34]$. The culture of professional self-realization as a part of Internet communication of students can be an open global (international) platform for the development of student culture, and based on the social significance of student culture, and a platform for further design and development of global cultural processes. The leading aspect of the modernization of education is to prepare the younger generation for the life in a rapidly changing information society, in a world where there is a constant need for new professions, for continuous professional development [35-41]. Currently, one of the main goals of innovation is the development of teacher abilities of the student to navigate independently in the world of information.

The problem of using information and communication technologies in training has been raised in the works of many foreign researchers [42-45]. In foreign literature, one can find scientific works on the practical use of information and communications technologies [46-50]. In addition, seminars on the use of information and communications technologies in trainings are held annually in many countries, demonstrating the widespread use of these technologies worldwide. It should be noted that modern technologies of teaching a foreign language are based on a communicative approach and include the use of various information and communications technologies that bring democracy, openness, and mobility to the educational process [51-56]. Information and communication technologies allow for interactions between a teacher and student. The use of information and communications technologies in education, in particular for foreign languages, has changed the approach to the development of educational material in a program discipline.

Currently, there is an objective need to integrate new learning technologies into the educational process, allowing students to more effectively form necessary competencies. One of the possible approaches is the widespread use of computer tools, both in the classroom and in the process of 
extracurricular educational and cognitive activity [55-58]. The use of information and computer technologies for learning a foreign language does not cause difficulties for students, because they already have instrumental competencies, including the skills of using a computer and social services. The use of interactive learning technologies is an objective necessity for a technical university due to the global informatization of education [59-62].

Although the organization of foreign language teaching in a technical university has become the subject of research for many domestic researchers [63-66], the analysis of scientific and methodological literature indicates the lack of theoretical and practical development of issues related to teaching foreign language professional communication to students in the light of modern requirements for interactive technologies of foreign language teaching.

In recent years, there have been a number of works [67-69] that have examined the educational potential of services of the internet in relation to foreign language learning. In most of these works, there was a tendency toward more and more active use of web 2.0 services in teaching types of speech activity. According to many authors [70-72], the web 2.0 service (in teaching aspects of languages) creates conditions for the ability to make responsible decisions in a situation of choice.

With the help of computer programs, interactive learning allows you to implement a range of methodological, didactic, pedagogical, and psychological principles; takes into account the individual speed of each student; and allows you to diversify forms of work and make the process of learning a foreign language more interesting and memorable [73-75]. For example, consider the means of information and communications technologies that are most often used in the educational process: Electronic textbooks and manuals demonstrated using a computer and a multimedia projector, electronic encyclopedias and reference books, simulators and testing programs, educational internet resources, DVD and CD discs with pictures and illustrations, video and audio equipment, research, and projects. It should be noted that information and communications technologies enable the teacher to exercise better control over the knowledge and skills of the student, rationally organize the educational process, and improve the efficiency of classes. Thanks to computer programs, educational material is presented more clearly and better than in oral form.

One of the most important facts is that a student can work in the classroom on an individual basis, progressing in the understanding of new educational material. Computer training programs give students the opportunity to train different types of speech activities and combine them in different combinations to realize language phenomena. Information and communications technologies contribute to the formation of linguistic abilities and the creation of communicative situations and allow you to automate language and speech actions as well as ensure the implementation of an individual approach and the intensification of the independent work of students [76-79]. Numerous educational online resources focus on learning a foreign language, allowing students to receive educational information through the exchange of text, video chats, and other means of online communication. In addition, the language environment provides users with teaching materials, in particular exercises and communications tools, tracking progress and allowing for engagement both individually and in a learning group. There are interactive resources that are not popular in Russia but are widely known throughout the world. They have been noted by researchers of scientific articles dealing with the topic of learning a foreign language in high school [80-83].

The concepts of "culture" and "activities" are located in historic relationships, and if a certain determination of the culture as a characteristic of activity is reflected in the orientation of a particular species, then there is a direct and inverse relationship between the process of development of personality culture and the ways of professional activities. Awareness of the goals of professional activities contributes to the actualization of personal professional qualities and creates conditions for constant self-regulation and self-knowledge. A true man of culture is capable of self-determination, independence, self-organization, self-realization, and self-improvement.

The main purpose of teaching a foreign language is to teach students the lexical and grammatical foundations of the language so that they can carry out basic communication with native speakers 
and implement simple practical tasks. The process of acquiring students' personal experience of communication in a foreign language requires the creation of situations of practical use of a foreign language as a tool of knowledge and interaction. Students form a priority to achieve communicative and cognitive competencies in English that are specified in the approximate program in nonlinguistic specialties of universities, which is important in the use of the studied language as a tool of communication. In this regard, the teacher of higher education is faced with the task of selecting the methods, means, and forms of foreign language teaching that contribute to the achievement of this goal.

It seems important to us that work on the development of the discipline provides a differentiation of educational tasks that also solves issues of the formation of professional speech of students, taking into account requirements for the preparation of a full range of specialists for all industries. In accordance with the studied sections of the course program, we concentrate on the number of exercises aimed at the development of professional speech. Modern students are focused on the widespread use of computers in everyday life, so the introduction of electronic resources in the training of professionally oriented foreign language will enhance the overall interest of students in the cognitive process.

Due to the rapid development of modern science and the update of terminology in all areas of knowledge, when studying a foreign language at a university, it is necessary to explore the best ways for its introduction and assimilation. The use of the Web 2.0 service, which allows for the implementation of mechanisms of independent work in an interactive mode, is a solution to one of the many existing problems of organizational and procedural nature associated with the teaching of a foreign language in a technical university $[84,85]$.

When using the currently existing diversity of information in communications technologies, it is necessary to take into account the fact that it has actually become available, in the mode of independent extracurricular work even more so than in classroom work. This is due to the fact that not all universities have the ability to provide computer classes for foreign language classes for all students, while more than $95 \%$ of students have personal computers and/or smart phones that provide them with access to the internet. Based on this circumstance, the modern teacher of a foreign language needs to rethink the role of independent work, which is now becoming much more important in the overall training of students in a foreign language.

In order to develop the ability to use the studied language in various situations of the domestic and professional sphere adequately and independently, it is necessary to create appropriate conditions for the educational environment. Thus, a focus on the self-educational activities of students as a necessary part of the process of learning a foreign language involves the use of new technologies, methods, and means of education in the educational process. Currently, the focus of teachers involves issues related to the improvement of the conditions of the organization of the independent work of students, the purpose of which is to develop analytical and creative thinking, increasing the level of responsibility for the results of educational activities. This should contribute to the task of ensuring the continuous formation of the professional level of the graduate that meets the modern requirements of society.

By independent work, we mean purposeful study of educational material by students and the development and improvement of their skills: The process organized by the teacher on the basis of the formation and activation of methods and means of the independent work of students aimed at the assimilation of knowledge and self-organization. To improve the independent work of the student, it is necessary that the teacher structures the activities of students, knowing the level of assimilation of the educational material and being able to teach them the techniques for independent performances of tasks [86-88]. The main strategy of the teacher in the organization of the independent work of the student is to involve the student in an active independent activity, which is interesting for students and motivates them. At the same time, it is necessary to take care to strengthen control over this work and the quality of the training tasks. 
The use of information and communications technologies as a means of organizing and managing a student's independent work leads to an increase in the efficiency of the educational process [89-91]. Automation of the knowledge control procedure allows for a more complete check of the level of training of students. In the traditional way of organizing, the control and self-control of knowledge are episodic, and a significant part of educational material is assimilated, controlled fluently, or not controlled at all due to lack of time. The use of interactive learning technology developed by us will help the teacher to solve problems of formation of strong communications skills and improve the vocabulary of students. Providing students with the opportunity to consolidate and activate the material explained by the teacher when they are performing algorithmized independent work in their extracurricular time gives real prospects for improving the quality of education, especially for a weak contingent of students [92]. The algorithm is widely used in different spheres of science, including pedagogy [93,94]. As a pedagogical support to enhance the interactivity of speech, we propose using the algorithm developed by us to compile statements by students, using conflicts, problems, and contradictions as an incentive to intensify the process of speaking.

It is necessary to fully use the vocabulary associated with the future profession of students, which also reflects the processes taking place in society. Working with terms requires broad interdisciplinary and metasubject connections, including the use of modern journalism, popular science texts, reference to terminological dictionaries, and dictionaries of foreign words [95-97]. In classroom work, in homework, and in practical classes we use different types of lexical exercises aimed at the development of students' vocabulary.

The implementation of such requirements in students' understanding of the main content of scientific texts, as well as the ability to outline the main provisions of special texts when reading, is impossible without technical university students sufficiently knowing terminological vocabulary. Knowledge of special terms in the framework of their direction in combination with foreign language communicative competence will help graduates of technical universities in situations of professional communication. Increased vocabulary of students made accessible through the use of focused electronic resources $[98,99]$. Information componence focused on the development of information culture will be of interest to us, first of all in the aspect of the use of electronic resources in the process of teaching professionally oriented foreign languages.

The integration of the content of foreign language teaching assumes, based on the application of the recommended integrative principle [100,101], a combination of the content of the main subject disciplines, the simultaneous development of both directly communicative and professionally communicative information, and academic knowledge, skills, and abilities. When organizing the learning process, it is recommended to shift the emphasis from classroom activities with a predominance of reproductive and training tasks to independent search and cognitive activities with different degrees of educational autonomy [102,103].

The most important condition for competent speech is the selection of lexical units for the expression of content $[104,105]$. Since we are going through a period of internationalization of the Russian language, a saturation of its borrowings from Western European languages, the task of the teacher is to develop students' correct attitudes toward ongoing language processes. On the one hand, there is a sense of patriotism about the Russian language and self-defense against the influx of foreign words and phrases and their excessive use in speech. On the other hand, there is the development of new vocabulary, which the professional sphere, especially the field of engineering, cannot do without. Students should know the vocabulary that reflects the realities of modern life and be able to use it.

Functional styles of speech are equally necessary for students of any specialty. For example, mastering the journalistic style is inextricably linked with the formation of certain qualities of the individual. Work on the journalistic style of speech should be tied to the daily life of the student, to his real life plans and his moral, aesthetic, and social values, and should be accessible to his perception and understanding so that special attention is paid to the choice of topics of these educational works. 
Based on our analysis of the existing literature on vocational education, the following contradictions are obvious: Between the need for the formation of foreign language communicative and cognitive competence and the lack of development of the cognitive-communicative component in teaching students to speak on professionally oriented topics; and between the requirement of a program in a foreign language to shift the emphasis from classroom activities with a predominance of reproductive and training tasks to independent search and cognitive activities with varying degrees of educational autonomy and the lack of development of algorithms for independent work with the use of information and communications technology. One of the forms of independent extracurricular work of students is the preparation of the text of any style and genre on a professional topic.

The implementation of monological utterance, which has been analyzed in many works [106-108], involved a three-phase process: Precommunicative, communicative, and postcommunicative stages. Due to the fact that the object of the study was a prepared monological utterance and that the element of spontaneity was automatically excluded from this type of activity, the primary aspect in the process of working on a statement was the planning of its content [109]. A disregard of the basic structure of a monological utterance by students led to difficulties associated with the process of perception, comprehension, and understanding of the spoken utterance toward a break in the two-way auditory channel [110]. In reality, there was a violation of the cyclical nature of the process: Speaking $\rightarrow$ listening $\rightarrow$ speaking.

First, in the process of making a monologue, $89 \%$ of students did not comply with its basic structure: The introduction, body, and conclusion. A monological utterance has a separate implication when the speaker influences the listeners [111]. Thus, leveling the significance of the first component of a monological utterance, which is an objective element that determines the aim for both the speaker and recipient, or reducing it to the phrases "I'd like to tell you about...", "I'd like to talk about ... ", "The topic of my speech today is ... ", etc., devalued students' utterances. The exclusion of conclusions from monological utterances led to an incomplete structure.

Second, some monological utterances were partially or completely irrelevant to the stated educational theme. Deviation from the educational theme was recorded both in the main part of monological utterances and in the conclusion, which did not correlate with the key idea of the speech. The reason for such errors was a lack of knowledge of students about the paragraph, which, like any monological utterance, was a three-component structure: (1) The idea of the paragraph, (2) the body, and (3) conclusions. Unconscious disregard of the dogma "one paragraph, one idea" resulted in the chaotic representation of a large number of ideas in monological utterances.

Third, a study of the program "Foreign Language: Basic Course, English" involved the acquaintance with and consolidation of lexical material on a specific topic and finally the use of the studied vocabulary in speech. The practice of teaching the making of monological utterances showed that in the process of final certification on the discipline, the students did not use the studied lexical material, which resulted in a lower exam mark. The reasons for ignoring vocabulary were (1) a lack of knowledge of lexical material, (2) insufficient lexical preparation of a monological utterance (the student knew the vocabulary, but did not think over the possibility of its usage in his monological utterance), and (3) a stressful situation (the student knew the vocabulary and thought over its usage in his monological utterance, but nervousness did not allow him to realize his knowledge in practice).

Another problem related to vocabulary was the lack of a unified list of lexical units for each section of the student's book. The lexical material, introduced in the dictionary of units, was limited to individual words, while in the process of working on monological utterances, the student must master not only the ability to communicate in the foreign language, which corresponds to universal competence in communication (UK-4), but must also be able to analyze and synthesize lexical material (systemic and critical thinking (UK-1)), i.e., be able to identify the appropriate lexeme for the specific communicative situation and use it in collocations and know idiomatic expressions on topics and use them in the right context. 
The lack of accurate requirements for the evaluation of a monological utterance led to their establishment in the course of the experiment. According to the developed parameters and criteria, the monological utterance must be a three-four-minute speech with 25-30 sentences. The total sum of points a student could get is 10 . All monological utterances were evaluated on five aspects: Content, fluency and pronunciation, organization of the utterance, vocabulary, and grammar. The context involved the level of topic development and the relevance of all elements of the monological utterance to the thesis. The coherence of each paragraph was achieved by the speaker's experience on the topic [112]. If the topic was developed and the content of the structural elements was fully coherent with the theme, this aspect was evaluated with 2 points; if the topic was developed but there were some insignificant deviations from the theme, this was 1 point; and if the topic was developed partially and there were numerous deviations, this was 0 points.

Fluency and pronunciation includes the right articulation of sounds, stressing sentences, logic, rhythm, and intonation as the cues to monologue perception [113-117]. The levels of fluency that are complex, high-order linguistic phenomena [118-121] have been developed in many works on linguistics [122]. If the speech was smooth and it contained no pauses and the pronunciation met the norm, the student got 2 points; if the speech was rather fast, but the same words were repeated and there were a few errors in the intonation, this was 1 point; and if the speech was slow, synonyms were not used, the intonation was improper, there was a lot of pausing, and it was difficult to understand the speaker, this was 0 points. The question of pausing was important, as the topic was general [123] in contrast to an academic monologue where the structure "speaking-pause-speaking" is organic [124].

The organization of the monological utterance involved both plan compliance and the use of linking words and phrases. A student got 1 point when all of the elements of the monological utterance were mentioned; 0.5 points- 1 point if an element was excluded; 0 points-more than 1 point if an element was excluded. As a student was provided with a list of linking words and phrases divided into eight categories (Addition, Examples, Cause, Purpose, Condition, Effect/Result/Consequence/Reason, Conclusion/Summary, and Opposition/Contradiction) and one extra group with all correlative conjunctions, to get 1 point at least one linker from each category and one correlative conjunction must have been used in the monologue. For 0.5 points, no less than one linker from six categories and one correlative conjunction must have been used, and for 0 points, less than six linkers and/no correlative conjunction would have been used.

To meet the vocabulary requirements, a student had to use no less than $75 \%$ of basic lexemes and at least one idiomatic expression. If $50 \%-75 \%$ of basic vocabulary was included into the utterance, the student got 0.5 points, and if less than $50 \%$ were used, 0 points. The lack of idioms was not evaluated at all (0 points). The lexical unit was taken into consideration only if it was pronounced right.

Grammar is regarded as the simplified rule system (a set of rules) that includes grammar mistakes such as wrong word order and prepositions, incorrect tenses, lack of articles, misuse of adverbs and adjectives, etc. If no more than four grammar mistakes were made and they did not affect listening and consequently understanding, 1 point was given; five-six grammar mistakes got 0.5 points; and more than six mistakes that affected the understanding of the utterance got 0 points. One more point could be given if a speaker used four or five unrepeated grammar constructions from the given list, such as passive voice, conditional clauses, modal verbs of deduction, indirect speech, sequence of tenses ( 0.5 points for three constructions and 0 points for less than three constructions). Despite the fact that lexical and grammatical aspects were separated to simplify the evaluation of the monological utterance, their cohesion was natural [125].

To eliminate the previously described shortcomings and errors, we developed authorized detailed maps of 24 monological utterances. The map of the monological utterance was a plan with accompanying instructions that allowed a student to make a monologue (Table 1) The monological utterance was divided into five steps, the first and the fifth of which were the introduction and conclusion, respectively. Here, a student could find specific tips, such as a hook sentence, which was usually excluded from the utterance, though it determined the success of the speech in terms of 
whether someone was listened to or not. Information about the differences between these two steps was introduced in the map of monological utterances as prompts. The second and the third steps were the ideas students were to cover in the course of their utterance. To stay within the context of the monological utterance, three sub-ideas were included in each of these steps. Despite the strict structure of the utterance, in the map of the monological utterance there was an opportunity for each student to speak about his ideas on the topic in the fourth step, "Creative Thinking".

Table 1. Map of the monological utterance on advertising \#1.

\begin{tabular}{|c|c|c|c|c|}
\hline & "You Are Going to Give a Talk about Advertising" & Basic Vocabulary & $\begin{array}{l}\text { Advanced } \\
\text { Vocabulary }\end{array}$ & $\begin{array}{c}\text { Linking Words and } \\
\text { Phrases }\end{array}$ \\
\hline \multicolumn{2}{|r|}{$\begin{array}{l}\text { REMEMBER! } \\
\text { Your speech will be graded according to the following criteria: }\end{array}$} & \multirow{2}{*}{\multicolumn{2}{|c|}{$\begin{array}{l}\text { Fill in the columns with words, colloce } \\
\text { functional language phrases, and linki } \\
\text { "Advertising". }\end{array}$}} & \\
\hline $\begin{array}{l}- \\
- \\
-\end{array}$ & $\begin{array}{l}\text { Relevance; } \\
\text { Coherence; } \\
\text { Fluency; } \\
\text { Grammar and vocabulary (see «parameters and criteria } \\
\text { for monological speech evaluation»). }\end{array}$ & & & $\begin{array}{l}\text { and idioms, } \\
\text { ords on the topic }\end{array}$ \\
\hline \multicolumn{2}{|c|}{ Step 1: Introduction } & \multirow[b]{2}{*}{$\begin{array}{l}\text { List of basic } \\
\text { lexemes }\end{array}$} & \multirow[b]{2}{*}{$\begin{array}{l}\text { List of advanced } \\
\text { lexemes }\end{array}$} & \multirow[b]{2}{*}{$\begin{array}{l}\text { List of linking words and } \\
\text { phrases }\end{array}$} \\
\hline $\begin{array}{l}2 \\
3\end{array}$ & $\begin{array}{l}\text { Make up a hook sentence that will attract a listener's } \\
\text { attention to your speech (a quote, proverb, } \\
\text { tongue-twister, etc.); } \\
\text { Lead your speech steadily to the second step; } \\
\text { An introduction consists of } 4-6 \text { sentences. }\end{array}$ & & & \\
\hline \multicolumn{2}{|r|}{ Step 3: Advertisements You Like and Dislike } & \multirow[b]{2}{*}{$\begin{array}{l}\text { List of basic } \\
\text { lexemes }\end{array}$} & \multirow[b]{2}{*}{$\begin{array}{l}\text { List of advanced } \\
\text { lexemes }\end{array}$} & \multirow[b]{2}{*}{$\begin{array}{l}\text { List of linking words and } \\
\text { phrases }\end{array}$} \\
\hline $\begin{array}{l}2 \\
3\end{array}$ & $\begin{array}{l}\text { Say some words about the attitudes of people } \\
\text { toward advertisements; } \\
\text { Describe the advertisements you dislike. Why? } \\
\text { Describe the advertisements you like. Why? }\end{array}$ & & & \\
\hline \multicolumn{2}{|r|}{$\begin{array}{l}\text { Step 4: Creative Thinking } \\
\text { Introduce your own extra idea(s) on advertising that has } \\
\text { not/have not been mentioned before. Substantiate your choice. }\end{array}$} & $\begin{array}{l}\text { List of basic } \\
\text { lexemes }\end{array}$ & $\begin{array}{l}\text { List of advanced } \\
\text { lexemes }\end{array}$ & $\begin{array}{l}\text { List of linking words and } \\
\text { phrases }\end{array}$ \\
\hline
\end{tabular}

To force and thus help students use topic vocabulary and linkers, the rest of the three columns were included: Basic vocabulary (separate words and collocations), advanced vocabulary (idiomatic expressions), and linkers. In the precommunicative stage, students filled cells in the table using the appendixes with the developed vocabulary in each unit. This planning allowed students to forecast their speech on the communicative stage in terms of the vocabulary they were going to use in each step and logically structured ideas. When the utterance was planned on this map, nervousness characterized by the feeling of apprehension and restlessness with a tensile feeling connected with the unexpected future were reduced significantly.

\section{Results}

The four-month experiment was carried out in the Institute of Applied Mathematics and Mechanics, Institute of Physics, Nanotechnology and Telecommunications, and the Institute of Computer Science and Technology of Peter the Great St. Petersburg Polytechnic University.

Throughout the experimental period, the students dealt with eight monological utterances on four topics: Advertising, education, design, and business, which corresponded to four stages. Before the experiment, students were asked to make a monologue on one of the topics, relying on their knowledge 
only. The analysis of those monological utterances showed the majority of students could get 5 of 10 points.

At the first stage, they were given the list of requirements and the maps of the monological utterances the students had to complete (Table 2) Despite the fact that the students had detailed instructions on the monologues, the first experience of making them was not successful. The average number of points they got was about 7 points out of 10 . The reasons were the lack of knowledge on the structure of the monologue, natural carelessness, and attempts to simplify the precommunicative stage. Thus, the monological utterances did not have appropriate structures, some parts of them were irrelevant, the sequences of ideas were illogical, and the percentage of lexical units used was still low. However, the use of maps allowed the students to find their own mistakes and get rid of them in the next monologues.

Thus, in the next stages, students showed steady progress that resulted in a higher average mark ( 8 points in the second stage, 8 and 8.5 points in the third stage, and 8.5 and more at the end of the experiment). Finally, students got used to the requirements for the monological utterance, and the completed maps of the monological utterances made their speeches worthy of higher marks. An example of such monological utterances is introduced in Figure 1, where linkers and basic and advanced vocabularies are singled out with blue, green, and red colors (Figure 1) It became evident that to attract the attention of listeners, it was better to use some shocking fact, paraphrased proverb, or funny story. The coherence of all elements of the monologue and the use of linking words and phrases provided a logical utterance that was understandable. The relevance of lexemes showed the progress of students and consequently enriched their active and passive vocabulary. The opportunity to plan the utterance resulted in fluency [126-130] based on the mechanism of controlled processing in terms of foreign language learning [131].

Table 2. Sample of the completed map of the monological utterance on advertising \#1.

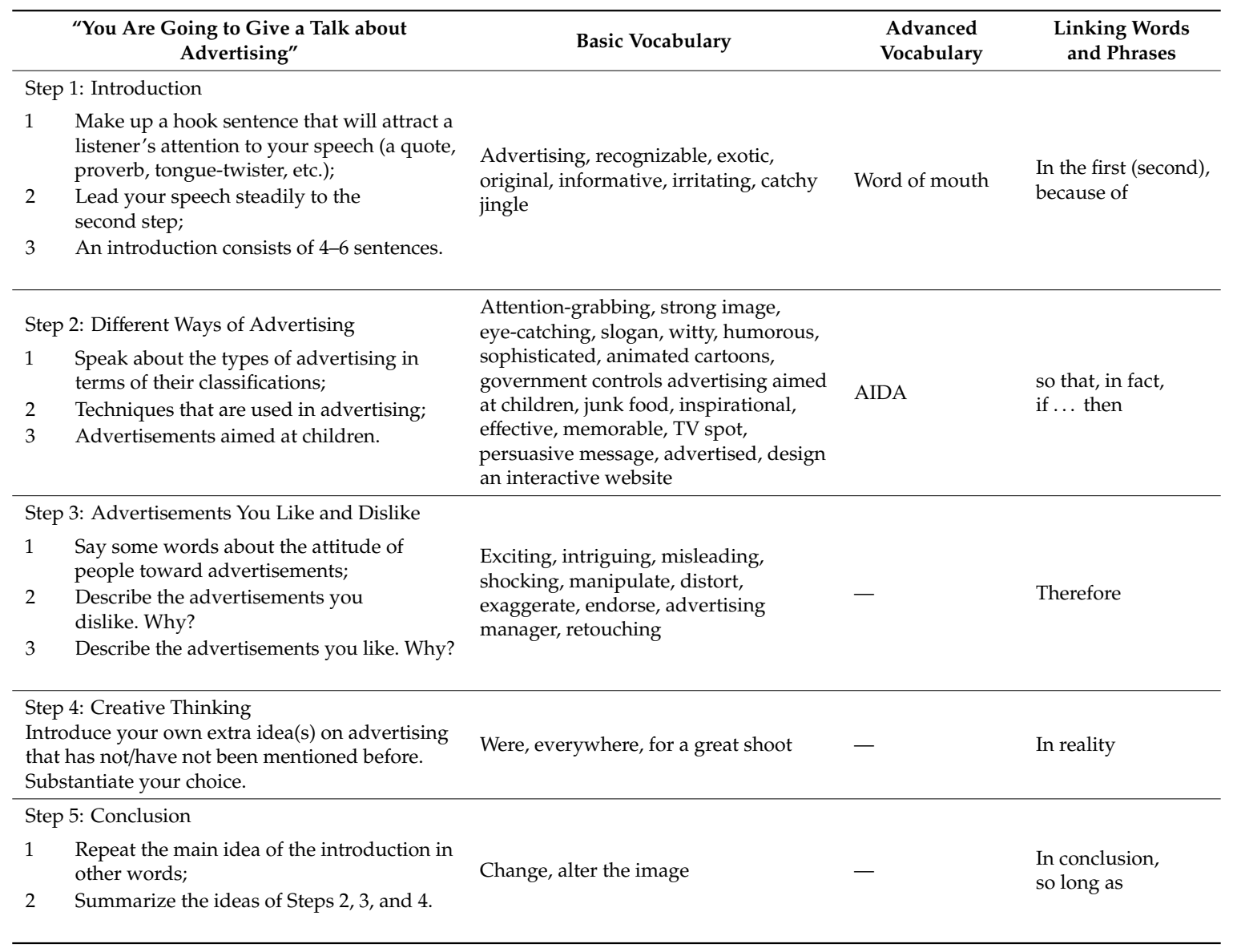


Today I want to tell you about advertising. Marshall McLuhan says that advertising is the greatest art of the $20^{\text {th }}$ century. He is right. In the first today advertising isn't ordinariness. Original, recognizable, exotic, informative or irritating advertising is everywhere. In the second they catch the eye, advertising is word of mouth and their melodies have catchy jingles and spin on the tongue. We have a lot of variety of advertising because of abundance of goods and market competition.

So that we can classify advert. This can be directed at women or men, children or adults. Goods can be advertised by TV, radio or poster. If the company wants people to buy goods then their advert should to be attention-grabbing, memorable and powerful, has a strong image that is eye-catching, a catchy slogan and persuasive message advertising shouldn't be dull. Also they can design an interactive website. In fact, many companies use the AIDA formula. Their short TV spot telling inspirational tales that are often witty, humorous and sophisticated. Children love the adverts because they are short, imaginative and often in the form of animated cartoons this is effective way to get attention. Some countries have governmental controls advertising aimed at children because some advert have a negative effect, like ads of junk-food.

Many people endorse advertising because it is exciting and intriguing. But in different opinion all of adverts are misleading, shocking, it manipulates people it distort and exaggerate the actual characteristics of the goods. Advertising manager can improve image using retouching. What about me I think that advertising is annoying, noisy and strange sometimes therefore I don't like any adverts.

I think that people have already invented all possible and impossible types of advertising, they were everywhere for a great shoot and I don't know what kind of advertising could surprise people but in reality we can see more and more different advertising.

In conclusion, I want to tell that advertising is art which created by creative people and advertising will be change or alter the image but never disappear so long as possible.

Figure 1. Monologue on advertising: "You are going to give a talk about advertising."

We applied the interactive technology of self-regulation formation to an experimental group of technical students. The interactive technology of self-regulation formation was based on the algorithmization of students' independent work in a foreign language, developed information technology support for students' understanding of course structures, and requirements for the performance of academic tasks. The algorithm of independent work developed by us provided a sufficiently high level of personal responsibility to the student for the results of educational work while providing the opportunity to independently select the sequence and time of study of educational material, as well as the use of new forms of control.

Some students studied new learning material on the basis of using the interactive technology of self-regulation formation, while in a control group, the training course was mastered in accordance with the requirements of the curriculum. The content of ordinary monologues of students did not reach its goal. The topic was not fully disclosed, and students demonstrated limited vocabulary. The possession of lexical and grammatical skills was insufficient to solve the problem of communication. The statement was constructed illogically and incoherently without the adequate use of a means of logical communication. An algorithmized statement allowed for (despite some artificiality in its content) the making of a more detailed and productive statement in comparison to a statement without the installation of algorithmization and artificial complication. Students were more likely to use the lexical and grammatical material of the textbook.

\section{Discussion}

As shown by a study conducted at Peter the Great St. Petersburg Polytechnic University, a federal state autonomous educational institution of higher education, the organization of classroom and independent work ensures a high level of student personal responsibility for the results of academic work, while ensuring the ability to independently choose the sequence and depth of learning material, etc. 
The experience showed that the students in the experimental group increased their level of professional training. The use of information and communications technologies by the student encourages him to constantly reflect, stimulating him to further action. Based on the study of the theoretical problems of the research, the analysis of resources, and experience in the practical application of interactive resources in teaching a foreign language, it is possible to identify a number of recommendations for teachers using information and communications technologies in interactive classes: The teacher and the student must be able to handle the computer at the level necessary to perform computer tasks; the teacher should clearly understand what forms of information and communications technologies should be used at this stage; the selected digital educational material must be adapted in accordance with the objectives and conditions of training; and the teacher should plan and organize independent student work on a subject with the involvement of information and communications technologies.

Based on the theoretical information given in the article, several conclusions were made. First, a student's age is favorable for the formation of the characteristics of the culture of self-realization of the individual, which is related to the future professional activities of students. In particular, this is the emerging motivation to perform a specific work activity, focus on self-improvement within it, and develop reflections on one's qualities as a future professional. Second, the concepts of "culture" and "activity" are interrelated, and since culture is a characteristic of activity, there is a direct and inverse relationship between the process of developing the culture of an individual and the way of to professional self-realization.

We also managed to find out that the classroom and extracurricular independent work of a high school student is characterized by a number of fundamental features: First, the student is responsible not only for storing, transferring, and using a specialized amount of knowledge, but also for its multiplication when his educational activities involve combined learning and research functions. Second, the student's activities are largely autonomous. This is explained by the fact that a student's competence can be assessed by both the teacher and himself according to predeveloped criteria. A very important incentive for a student is the recognition of his learning activities by a teacher who is able to evaluate his intellectual efforts. This also serves as a condition for preserving the autonomy of the student himself, a means of internal control and self-regulation. It is concluded that an important form of reflecting the results of students' professional self-realization in the learning process is its activity in the role of a student who is able to set a task and lead its implementation. As a basic mechanism for the self-realization of a Russian student in the learning process, his attitude toward self-education activities and his place in it stands. A similar study was conducted to identify the features of self-realization of students of humanitarian and technological universities [132]. The work carried out on the whole showed the fruitfulness of the sociocultural determination of the study of the problem of students' self-realization, since it revealed a universal mechanism for students' self-realization. At the personality level, this mechanism consists of the realization of culture in oneself, and not oneself in culture, in particular in the development of value relations, which are initially opened not so much in the internal plan as in the sociocultural sphere, in constant movement as the student dedicates himself to something more significant than self (study, profession, science, country, society, culture, etc.). Such an approach can serve as a productive basis for understanding higher education as a field for self-realization, as a sociocultural space for the search for meanings and ways to apply the essential forces of students not only in a local context and in a community but also in global and national arenas.

\section{Conclusions}

In conclusion, we state that despite the undoubted theoretical and practical significance of the research, the problem of effective use of information and communications technologies in the educational process remains open to theoretical understanding and experimental research. The development and introduction of new technologies in this area will contribute to the further development of the theory and methodology of vocational education. 
The use of information and communications technologies in teaching a foreign language increases the interest of students in a subject and enhances their speech-thinking activities, contributing to the development of skills in independent classroom and extracurricular work. Through the solution of cognitive tasks, the mutual understanding of speakers of different languages is provided through the allocation of their common and nationally specific messages. Thus, there are opportunities for dialogue in cultures through the language of communication. Thus, both in foreign language classes and in extracurricular activities, students should create a situation of communication, modeling the dialogue of cultures.

It is necessary to acquaint students with the subject of country studies, look for ways to include them in an active dialogue of cultures, and acquaint them with the algorithms of educational and speech actions so that they can learn in practice the features of the functioning of language in a culture new to them. It is also important to ensure the study of the structures of statements and the choice of interaction strategies. It is necessary to give students the opportunity to solve various problems that give rise to thought and to discuss possible ways of solving these problems so that students focus not only on the content of their statements, but also on correct linguistic design, taking into account linguistic and cultural aspects. Fluency in the rich vocabulary of modern English and the ability to communicate these days are becoming essential components of any professional activity. What a person says may depend on the results of his work. The level of culture of modern man largely depends on the degree of proficiency in a foreign language and speech and the ability to communicate in a certain speech situation. This is especially true for people who have chosen an engineer. The discipline "professional language and culture of speech" allows for the formation of communicative competence in future teachers learning all the circumstances. The obvious conclusion is that systematic work with computer tasks forms sustainable skills for the independent classroom and extracurricular work of students, which leads to a reduction in time to perform standard tasks and increases the time to perform creative work.

Author Contributions: Conceptualization, M.O., O.S. and T.K.; Methodology, T.K. and O.S.; Validation: O.S.; Formal analysis, M.O., T.K. and O.S.; Investigation, M.O., O.S., M.B. and T.K.; Resources, M.O., O.S., M.B., T.K.; Writing-Original Draft Preparation, M.O., T.K., O.S. and M.B.; Writing-review and editing, O.S., M.B. and M.O.; Visualization, M.O., O.S.; Supervision, M.B. and T.K.; Project administration, T.K.

Funding: This research received no external funding.

Conflicts of Interest: The authors declare no conflicts of interest.

\section{References}

1. Barnes, M.E.; Brownell, S.E. A call to use cultural competence when teaching evolution to religious college students: Introducing religious cultural competence in evolution education (ReCCEE). CBE Life Sci. Educ. 2017, 16, es4. [CrossRef] [PubMed]

2. Hamidi, H.; Chavoshi, A. Analysis of the essential factors for the adoption of mobile learning in higher education: A case study of students of the University of Technology. Telemat. Informa. 2018, 35, 1053-1070. [CrossRef]

3. Harrison, C.J.; Könings, K.D.; Schuwirth, L.W.T.; Wass, V.; Van der Vleuten, C.P.M. Changing the culture of assessment: The dominance of the summative assessment paradigm. BMC Med. Educ. 2017, 17, 73. [CrossRef] [PubMed]

4. Hoda, R.; Babar, M.A.; Shastri, Y.; Yaqoob, H. Socio-Cultural Challenges in Global Software Engineering Education. IEEE Trans. Educ. 2017, 60, 173-182. [CrossRef]

5. Huda, M.; Sabani, N.; Shahrill, M.; Jasmi, K.A.; Basiron, B.; Mustari, M.I. Empowering learning culture as student identity construction in higher education. In Student Culture and Identity in Higher Education; IGI Global: Hershey, PA, USA, 2017; pp. 160-179.

6. Biesta, G. Education, measurement and the professions: Reclaiming a space for democratic professionality in education. Educ. Philos. Theory. 2017, 49, 315-330. [CrossRef] 
7. Pugacheva, N.B.; Ezhov, S.G.; Kozhanov, I.V.; Kozhanova, M.B.; Ogorodnikova, S.V.; Oshaev, A.G.; Timonin, A.I.; Goloshumova, G.S. The model of self-realization readiness formation of research universities students in the process of civic education. Int. Rev. Manag. Mark. 2016, 6, 128-133.

8. Medvedeva, T.Y.; Kazantseva, G.A.; Mineeva, O.A.; Karpukova, A.A.; Daricheva, M.V. Design of professional career by future experts in the sphere of art and culture. Eur. Res. Stud. J. 2015, 18, 223-230.

9. Gorbunova, E.E. Model of process of training of future experts in the sphere of culture for professional and creative self-realization. In Scientific Magazine "News of the Volgograd State Pedagogical University"; Volgograd State Pedagogical University: Volgograd, Russia, 2010.

10. Khrulyova, A.A.; Sakhieva, R.G. Forming of informational culture as a necessary condition of the level raising of higher education. Man India 2017, 97, 211-225.

11. Gendina, N.I. Informational culture, creativity and creativity of the graduate of the higher school in the context of problems of development of the human capital of information society. Inf. Soc. 2009, 2, 57-63.

12. Ramankulov, S.; Usembaeva, I.; Berdi, D.; Omarov, B.; Baimukhanbetov, B.; Shektibayev, N. Formation of the Creativity of Students in the Context of the Education Informatization. Int. J. Environ. Sci. Educ. 2016, 11, 9598-9613.

13. Kargina, E.M. Efficiency of Training of Engineers in the Conditions of Educational Environment Profiling of Technical Higher Education. Contemp. Eng. Sci. 2015, 2, 49-56. [CrossRef]

14. Shutenko, E.N.; Kanishcheva, M.A.; Kovtun, J.J.; Derevyanko, J.P.; Shutenko, A.I. Provide students' self-fulfillment through the application of modern information technology in higher education. J. Fundam. Appl. Sci. 2017, 9, 960-970. [CrossRef]

15. Sagitova, R.R.; Khasanova, N.F. The formation of self-educational competence of university students in the process of foreign language learning. Turk. Online J. Des. Art Commun. 2016, 6, 2525-2529.

16. Bathmaker, A.-M.; Avis, J. Becoming a lecturer in further education in England: The construction of professional identity and the role of communities of practice. J. Educ. Teach. 2005, 31, 47-62. [CrossRef]

17. Strouse, S.M.; Nickerson, C.J. Professional culture brokers: Nursing faculty perceptions of nursing culture and their role in student formation. Nurse Educ. Pract. 2016, 18, 10-15. [CrossRef] [PubMed]

18. Kenny, N.P.; Mann, K.V.; MacLeod, H. Role modeling in physicians' professional formation: Reconsidering an essential but untapped educational strategy. Acad. Med. 2003, 78, 1203-1210. [CrossRef] [PubMed]

19. Richardson, S.; Asthana, S. Inter-agency information sharing in health and social care services: The role of professional culture. Br. J. Soc. Work 2006, 36, 657-669. [CrossRef]

20. Juárez-Nájera, M.; Dieleman, H.; Turpin-Marion, S. Sustainability in Mexican Higher Education: Towards a new academic and professional culture. J. Clean. Prod. 2006, 14, 1028-1038. [CrossRef]

21. Marincioni, F. Information technologies and the sharing of disaster knowledge: The critical role of professional culture. Disasters 2007, 31, 459-476. [CrossRef]

22. Janus, $\mathrm{K}$. The effect of professional culture on intrinsic motivation among physicians in an academic medical center. J. Healthcare Manag. 2014, 59, 287-304. [CrossRef]

23. Khairullina, E.R.; Makhotkina, L.Y.; Kiryakova, A.V.; Baranov, V.V.; Maksimova, O.G.; Khrisanova, E.G.; Piralova, O.F.; Masalimova, A.R. The real and the ideal engineer-technologist in the view of employers and educators. Int. Rev. Manag. Mark. 2016, 6, 134-138.

24. Hall, P. Interprofessional teamwork: Professional cultures as barriers. J. Interprof. Care. 2005, 19 (Suppl. 1), 188-196. [CrossRef] [PubMed]

25. Carlson, S. Becoming a Mobile Student-A Processual Perspective on German Degree Student Mobility. Popul. Space Place 2013, 19, 168-180. [CrossRef]

26. Brooks, R.; Waters, J. Social networks and educational mobility: The experiences of UK students. Glob. Soc. Educ. 2010, 8, 143-157. [CrossRef]

27. Walasek, T.; Piątkowski, J.; Morawska-Walasek, D. Information Technologies supporting students' mobility. J. Ach. Mater. Manuf. Eng. 2007, 25, 83-86.

28. Burkle, M. E-learning challenges for polytechnic institutions: Bringing e-mobility to hands-on learning. In Digital Literacy: Concepts, Methodologies, Tools, and Applications; IGI Publishing: Hershey, NY, USA, 2013; pp. 1008-1025.

29. Barragán Codina, J.N.; Leal López, R.H. The importance of student mobility, academic exchange and internationalization of higher education for college students in a globalized world: The Mexican and Latin American case. Daena Int. J. Good Consci. 2013, 8, 48-63. 
30. Hull, G.A. At last: Youth culture and digital media: New literacies for new times. Res. Teach. Eng. 2003, 38, 229-233.

31. Tavin, K. Teaching in and through visual culture. J. Cult. Res. Art Educ. 2000, 18, 37.

32. Buckingham, D.; Sefton-Green, J. Multimedia education: Media literacy in the age of digital culture. In Media Literacy in the Information Age; Transaction Publishers: New Brunswick, NJ, USA, 1997; pp. 285-305.

33. Cheung, W.; Huang, W. Proposing a framework to assess Internet usage in university education: An empirical investigation from a student's perspective. Br. J. Educ. Technol. 2005, 36, 237-253. [CrossRef]

34. Sponcil, M.; Gitimu, P. Use of social media by college students: Relationship to communication and self-concept. J. Technol. Res. 2013, 4, 1.

35. Almazova, N.; Baranova, T.; Khalyapina, L. Development of students' polycultural and ethnocultural competences in the system of language education as a demand of globalizing world. Adv. Intell. Syst. Comput. 2019, 907, 145-156.

36. Almazova, N.; Barinova, D.; Ipatov, O. Forming of information culture with tools of electronic didactic materials. Ann. DAAAM Proc. 2018, 29, 587-593.

37. Almazova, N.; Andreeva, S.; Khalyapina, L. The integration of online and offline education in the system of students' preparation for global academic mobility. Commun. Comput. Inf. Sci. 2018, 859, 162-174.

38. Almazova, N.I.; Kostina, E.A.; Khalyapina, L.P. The new position of foreign language as education for global citizenship. Novosib. State Pedag. Univ. Bull. 2016, 6, 7-17. [CrossRef]

39. Rudskoy, A.I.; Borovkov, A.I.; Romanov, P.I.; Kolosova, O.V. Ways to reduce risks when building the digital economy in Russia. Vysshee Obrazovanie v Rossii. 2019, 28, 9-22. [CrossRef]

40. Rudskoy, A.I.; Borovkov, A.I.; Romanov, P.I. Russian experience in engineering education development. Vysshee Obrazovanie v Rossii 2018, 27, 151-162.

41. Rudskoy, A.I.; Borovkov, A.I.; Romanov, P.I.; Kolosova, O.V. General professional competence of a modern Russian engineer. Vysshee Obrazovanie v Rossii 2018, 27, 5-18.

42. Ertmer, P.A.; Ottenbreit-Leftwich, A.T. Teacher technology change: How knowledge, confidence, beliefs, and culture intersect. J. Res. Technol. Educ. 2010, 42, 255-284. [CrossRef]

43. Evans, C. The effectiveness of m-learning in the form of podcast revision lectures in higher education. Comput. Educ. 2008, 50, 491-498. [CrossRef]

44. Pelgrum, W.J. Obstacles to the integration of ICT in education: Results from a worldwide educational assessment. Comput. Educ. 2001,37, 163-178. [CrossRef]

45. Sang, G.; Valcke, M.; Braak, J.V.; Tondeur, J. Student teachers' thinking processes and ICT integration: Predictors of prospective teaching behaviors with educational technology. Comput. Educ. 2010, 54, 103-112. [CrossRef]

46. Buabeng-Andoh, C. Factors Influencing Teachers' Adoption and Integration of Information and Communication Technology into Teaching: A Review of the Literature. Int. J. Educ. Dev. Using ICT 2012, 8, 136-155.

47. Kirkwood, A.; Price, L. Adaptation for a Changing Environment: Developing Learning and Teaching with Information and Communication Technologies. Int. Rev. Res. Open Distance Learn. 2006, 7, 1-14. [CrossRef]

48. Chai, C.S.; Koh, J.H.L.; Tsai, C.C.; Tan, L.L.W. Modeling primary school pre-service teachers' Technological Pedagogical Content Knowledge (TPACK) for meaningful learning with information and communication technology (ICT). Comput. Educ. 2011, 57, 1184-1193. [CrossRef]

49. Daniela, L.; Visvizi, A.; Gutiérrez-Braojos, C.; Lytras, M.D. Sustainable higher education and Technology-Enhanced Learning (TEL). Sustainability 2018, 10, 3883. [CrossRef]

50. Martínez-Argüello, L.D.; Hinojo-Lucena, F.J.; Díaz, I.A. Application of Information and Communication Technologies (ITC) in teaching-learning processes by chemistry teachers. Inf. Tecnol. 2018, 29, 41-52. [CrossRef]

51. Albirini, A. Teachers' attitudes toward information and communication technologies: The case of Syrian EFL teachers. Comput. Educ. 2006, 47, 373-398. [CrossRef]

52. Slaouti, D.; Barton, A. Opportunities for practice and development: Newly qualified teachers and the use of information and communications technologies in teaching foreign languages in English secondary school contexts. J. Serv. Educ. 2007, 33, 405-424. [CrossRef]

53. Agca, R.K.; Özdemir, S. Foreign language vocabulary learning with mobile technologies. Procedia Soc. Behav. Sci. 2013, 83, 781-785. [CrossRef] 
54. Kramsch, C. Teaching foreign languages in an era of globalization: Introduction. Mod. Lang. J. 2014, 98, 296-311. [CrossRef]

55. Mikre, F. The roles of information communication technologies in education: Review article with emphasis to the computer and internet. Ethiop. J. Educ. Sci. 2011, 6, 109-126.

56. Liu, J. A survey of EFL learners' attitudes toward information and communication technologies. Eng. Lang. Teach. 2009, 2, 101-106. [CrossRef]

57. Goodwin, K.; Kennedy, G.; Vetere, F. Getting together out-of-class: Using technologies for informal interaction and learning. Curric. Technol. Transform. Unkn. Future. 2010, 387-392.

58. Deepwell, F.; Malik, S. On campus, but out of class: An investigation into students' experiences of learning technologies in their self-directed study. ALT J. 2008, 16, 5-14. [CrossRef]

59. Kopf, S.; Effelsberg, W. New teaching and learning technologies for interactive lectures. Adv. Technol. Learn. J. 2007, 4, 60-67. [CrossRef]

60. Agbatogun, A.O. Interactive digital technologies' use in Southwest Nigerian universities. Educ. Technol. Res. Dev. 2013, 61, 333-357. [CrossRef]

61. Khan, A.W.; McWilliams, P. Application of interactive technologies in open and distance learning: An overview. Indian J. Open Learn. 1998, 7, 7-21.

62. Hennessy, S.; Warwick, P. Research into teaching with whole-class interactive technologies. Technol. Pedag. Educ. 2010, 19, 127-131. [CrossRef]

63. Gömleksi, M.N. Effectiveness of cooperative learning (jigsaw II) method in teaching English as a foreign language to engineering students (Case of Firat University, Turkey). Eur. J. Eng. Educ. 2007, 32, 613-625. [CrossRef]

64. Basal, A. The implementation of a flipped classroom in foreign language teaching. Turk. Online J. Distance Educ. 2015, 16, 28-37. [CrossRef]

65. Karatas, H.; Alci, B.; Bademcioglu, M.; Ergin, A. An Investigation into University Students. Foreign Language Speaking Anxiety. Procedia Soc. Behav. Sci. 2016, 232, 382-388. [CrossRef]

66. Kırkgöz, Y. Students' and lecturers' perceptions of the effectiveness of foreign language instruction in an English-medium university in Turkey. Teach. High. Educ. 2009, 14, 81-93. [CrossRef]

67. Grosseck, G. To use or not to use web 2.0 in higher education? Procedia Soc. Behav. Sci. 2009, 1, 478-482. [CrossRef]

68. Bennett, S.; Bishop, A.; Dalgarno, B.; Waycott, J.; Kennedy, G. Implementing Web 2.0 technologies in higher education: A collective case study. Comput. Educ. 2012, 59, 524-534. [CrossRef]

69. Collis, B.; Moonen, J. Web 2.0 tools and processes in higher education: Quality perspectives. Educ. Media Int. 2008, 45, 93-106. [CrossRef]

70. Stevenson, M.P.; Liu, M. Learning a language with Web 2.0: Exploring the use of social networking features of foreign language learning websites. CALICO J. 2013, 27, 233-259. [CrossRef]

71. Oskoz, A.; Elola, I. Meeting at the wiki: The new arena for collaborative writing in foreign language courses. In Web 2.0-Based E-Learning: Applying Social Informatics for Tertiary Teaching; IGI Global: Hershey, PA, USA, 2011; pp. 209-227.

72. Hsu, L. English as a foreign language learners' perception of mobile assisted language learning: A cross-national study. Comput. Assist. Lang. Learn. 2013, 26, 197-213. [CrossRef]

73. Kinginger, C.; Belz, J.A. Socio-cultural perspectives on pragmatic development in foreign language learning: Microgenetic case studies from telecollaboration and residence abroad. Intercult. Pragmat. 2005, 2, 369-421. [CrossRef]

74. Shih, Y.-C.; Yang, M.-T. A collaborative virtual environment for situated language learning using VEC3D. Educ. Technol. Soc. 2008, 11, 56-68.

75. Lee, L. Enhancing learners' communication skills through synchronous electronic interaction and task-based instruction. Foreign Lang. Ann. 2002, 35, 16-23. [CrossRef]

76. Forcheri, P.; Molfino, M.T.; Quarati, A. ICT driven individual learning: New opportunities and perspectives. Educ. Technol. Soc. 2000, 3, 51-61.

77. Kassim, H.; Ali, Z. The Use of ICT in the Implementation of Student-Centered Learning (SCL). Int. J. Lang. Learn. Teach. 2007, 4, 15-31.

78. Klimov, B.F. ICT versus traditional approaches to teaching. Procedia Soc. Behav. Sci. 2012, 47, 196-200. [CrossRef] 
79. Smeets, E. Does ICT contribute to powerful learning environments in primary education? Comput. Educ. 2005, 44, 343-355. [CrossRef]

80. Jin, L.; Deifell, E. Foreign language learners' use and perception of online dictionaries: A survey study. J. Online Learn. Teach. 2013, 9, 515.

81. Hao, Y. Middle school students' flipped learning readiness in foreign language classrooms: Exploring its relationship with personal characteristics and individual circumstances. Comput. Hum. Behav. 2016, 59, 295-303. [CrossRef]

82. Alm, A. Extensive listening 2.0 with foreign language podcasts. Innov. Lang. Learn. Teach. 2013, 7, $266-280$. [CrossRef]

83. Liu, M. The design of a web-based course for self-directed learning. Campus Wide Inf. Syst. 2009, 26, $122-131$. [CrossRef]

84. Nazarenko, A.L. Blended learning vs traditional learning: What works? Procedia Soc. Behav. Sci. 2015, 200, 77-82. [CrossRef]

85. Verhoeven, J.C.; Heerwegh, D.; De Wit, K. First year university students' self-perception of ICT skills: Do learning styles matter? Educ. Inf. Technol. 2012, 17, 109-133. [CrossRef]

86. Leidner, D.E.; Fuller, M. Improving student learning of conceptual information: GSS supported collaborative learning vs. individual constructive learning. Decis. Support Syst. 1997, 20, 149-163. [CrossRef]

87. Baldwin, T.T.; Bedell, M.D.; Johnson, J.L. The social fabric of a team-based MBA program: Network effects on student satisfaction and performance. Acad. Manag. J. 1997, 40, 1369-1397.

88. Slavin, R.E. When does cooperative learning increase student achievement? Psychol. Bull. 1983, 94, 429. [CrossRef]

89. Haddad, W.; Jurich, S. ICT for education: Potential and potency. Technologies for education: Potential, parameters and prospects. UNESCO Acad. Educ. Dev. 2002, 28-40.

90. De Witte, K.; Rogge, N. Does ICT matter for effectiveness and efficiency in mathematics education? Comput. Educ. 2014, 75, 173-184. [CrossRef]

91. Krishnaveni, R.; Meenakumari, J. Usage of ICT for Information Administration in Higher education Institutions-A study. Int. J. Environ. Sci. Dev. 2010, 1, 282-286. [CrossRef]

92. McCabe, D.L. The influence of situational ethics on cheating among college students. Sociol. Inq. 1992, 62,365-374. [CrossRef]

93. Chusov, A.A.; Statsenko, L.G.; Anisimov, P.N.; Cherkasova, N.A.; Bernavskaya, M.V. Computer Simulation of an Arbitrary Acoustical Field in Rooms. In Proceedings of the Asia Modelling Symposium (AMS), Kota Kinabalu, Malaysia, 4-6 December 2017.

94. Chusov, A.A.; Statsenko, L.G.; Lysenko, A.P.; Unru, P.P.; Bernavskaya, M.V. Parallel Acoustic Field Simulation with Respect to Scattering of Sound on Local Inhomogeneities. Procedia Soc. Behav. Sci. 2017, 108, 1753-1762. [CrossRef]

95. Gorev, P.M.; Masalimova, A.R. Development of meta-subject competencies of the 7-9 grades basic school students through the implementation of interdisciplinary mathematical courses. Eurasia J. Math. Sci. Technol. Educ. 2017, 13, 3919-3933.

96. Platonova, R.I.; Golokova, V.S.; Ammosova, L.I.; Barkalova, N.V.; Zorina, A.V.; Vygodchikova, N.N.; Chernova, Y.A. The implementation of trans-disciplinary principle in the content of higher school students humanitarian training. Int. Rev. Manag. Mark. 2016, 6 (Suppl. 2), 56-50.

97. Spelt, E.J.; Biemans, H.J.; Tobi, H.; Luning, P.A.; Mulder, M. Teaching and learning in interdisciplinary higher education: A systematic review. Educ. Psychol. Rev. 2009, 21, 365. [CrossRef]

98. Read, J. Research in teaching vocabulary. Annu. Rev. Appl. Linguist. 2004, 24, 146-161. [CrossRef]

99. Godwin-Jones, R. Emerging technologies from memory palaces to spacing algorithms: Approaches to second language vocabulary learning. Lang. Learn. Technol. 2010, 14, 4.

100. Saunders, M. The integrative principle: Higher education and work-based learning in the UK. Eur. J. Educ. 1995, 30, 203-216. [CrossRef]

101. Crisp, G.T. Integrative assessment: Reframing assessment practice for current and future learning. Assess. Eval. High. Educ. 2012, 37, 33-43. [CrossRef]

102. Bonneville-Roussy, A.; Vallerand, R.J.; Bouffard, T. The roles of autonomy support and harmonious and obsessive passions in educational persistence. Learn. Ind. Differ. 2013, 24, 22-31. [CrossRef] 
103. Lo, W.Y.W. Decentralization of higher education and its implications for educational autonomy in Taiwan. Asia Pac. J. Educ. 2010, 30, 127-139. [CrossRef]

104. Dhooge, E.; Hartsuiker, R.J. Lexical selection and verbal self-monitoring: Effects of lexicality, context, and time pressure in picture-word interference. J. Mem. Lang. 2012, 66, 163-176. [CrossRef]

105. Almela, M.; Sánchez, A. Words as "lexical units" in learning/teaching vocabulary. Int. J. Eng. Stud. 2007, 7, 21-40.

106. Delin, J. Keeping in step: Task structure, discourse structure, and utterance interpretation in the step aerobics workout. Discourse Process. 2001, 31, 61-89. [CrossRef]

107. Johnson, N.A.R.; Lane, D.M. Narrative monologue as a first step towards advanced mission debrief for AUV operator situational awareness. In Proceedings of the 15th International Conference on Advanced Robotics: New Boundaries for Robotics (ICAR), Tallinn, Estonia, 20-23 June 2011.

108. Watanabe, M.M. Conflict and intolerance in a web community: Effects of a system integrating dialogues and monologues. J. Comput. Med. Commun. 2007, 12, 1020-1042. [CrossRef]

109. Fawcett, R.P.; Davies, B.L. Monologue as a turn in dialogue: Towards an integration of exchange structure and rhetorical structure theory. Lect. Notes Comput. Sci. 1992, 587, 151-166.

110. Redeker, G. Ideational and pragmatic markers of discourse structure. J. Pragmat. 1990, 14, 367-381. [CrossRef]

111. Fay, N.; Garrod, S.; Carletta, J. Group Discussion as Interactive Dialogue or as Serial Monologue: The Influence of Group Size. Psychol. Sci. 2000, 11, 481-486. [CrossRef] [PubMed]

112. Hovy, E.H. Unresolved Issues in Paragraph Planning; Academic Press Professional, Inc.: San Diego, CA, USA, 1990.

113. Kleinhans, J.; Farrús, M.; Gravano, A.; Lai, C.; Wanner, L. Using prosody to classify discourse relations. In Proceedings of the Annual Conference of the International Speech Communication Association, Stockholm, Sweden, 14-21 March 2017.

114. Korotaev, N.A. Elementary discourse units in spoken monologues: Evidence from communicative prosody. Komp'juternaja Lingvistika i Intellektual'nye Tehnologii 2010, 1, 294-307.

115. Stoyanchev, S.; Piwek, P. Constructing the CODA corpus: A parallel corpus of monologues and expository dialogues. In Proceedings of the 7th International Conference on Language Resources and Evaluation (LREC), Valletta, Malta, 19-21 May 2010.

116. Swerts, M.; Geluykens, R. The prosody of information units in spontaneous monologue. Phonetica 1993, 50, 189-196. [CrossRef] [PubMed]

117. Swerts, M.; Geluykens, R. Prosody as a Marker of Information Flow in Spoken Discourse. Lang. Speech 1994, 37, 21-43. [CrossRef]

118. Chambers, F. What do we mean by fluency? System 1997, 25, 535-544. [CrossRef]

119. Cucchiarini, C.; Strik, H.; Boves, L. Quantitative assessment of second language learners' fluency: Comparisons between read and spontaneous speech. J. Acoust. Soc. Am. 2002, 111, 2862-2873. [CrossRef]

120. De Jong, N.; Perfetti, C.A. Fluency Training in the ESL Classroom: An Experimental Study of Fluency Development and Proceduralization. Lang. Learn. 2011, 61, 533-568. [CrossRef]

121. Riggenrach, $\mathrm{H}$. Toward an understanding of fluency: A microanalysis of nonnative speaker conversations. Discourse Process. 1991, 14, 423-441. [CrossRef]

122. Kormos, J.; Dénes, M. Exploring measures and perceptions of fluency in the speech of second language learners. System 2004, 32, 145-164. [CrossRef]

123. Bogdanova-Beglarian, N. In search of sentence boundaries in spontaneous speech. Lect. Notes Comput. Sci. 2017, 10458, 456-463.

124. Rendle-Short, J. Managing the transitions between talk and silence in the academic monologue. Res. Lang. Soc. Interact. 2005, 38, 179-218. [CrossRef]

125. Thompson, S. Aspects of Cohesion in Monologue. Appl. Linguist. 1994, 15, 58-75. [CrossRef]

126. Ellis, R. The differential effects of three types of task planning on the fluency, complexity, and accuracy in L2 oral production. Appl. Linguist. 2009, 30, 474-509. [CrossRef]

127. Foster, P.; Skehan, P. The influence of planning and task type on second language performance. Stud. Second Lang. Acquis. 1996, 18, 299-323. [CrossRef]

128. Skehan, P. Modelling second language performance: Integrating complexity, accuracy, fluency, and lexis. Appl. Linguist. 2009, 30, 510-532. [CrossRef] 
129. Skehan, P.; Foster, P.; Shum, S. Ladders and Snakes in Second Language Fluency. Int. Rev. Appl. Linguist. Lang. Teach. 2016, 54, 97-111. [CrossRef]

130. Yuan, F.; Ellis, R. The Effects of Pre-Task Planning and On-Line Planning on Fluency, Complexity and Accuracy in L2 Monologic Oral Production. Appl. Linguist. 2003, 24, 1-27. [CrossRef]

131. Schmidt, R. Psychological mechanisms underlying second language fluency. Stud. Second Lang. Acquis. 1992, 14, 357-385. [CrossRef]

132. Shutenko, E.M. Self-realization of students in modern university as the humanitarian problem of youth socialization. Perspect. Sci. Educ. 2014, 1, 149-152.

(C) 2019 by the authors. Licensee MDPI, Basel, Switzerland. This article is an open access article distributed under the terms and conditions of the Creative Commons Attribution (CC BY) license (http://creativecommons.org/licenses/by/4.0/). 